\title{
Effects of Inputs from the Preconstruction Activities on the Design Phase of Construction Projects
}

\section{Leelanath Daluwatte and Malik Ranasinghe}

\begin{abstract}
Success of the design of a project would depend on the adequacy of its inputs. The adequacy of inputs from the preconstruction activities is important to achieve effective delivery of a design and then the construction project. This study focused on identifying the relevant preconstruction activities and analyzing the adequacy of use of the outputs of preconstruction activities as inputs to the design of construction projects.
\end{abstract}

Thirty eight design phase related preconstruction activities were identified through literature review. Data was collected using a structured questionnaire regarding the adequacy of the inputs from the identified preconstruction activities to the design phase from the professionals involved in construction projects in the industry.

The data was analysed by multiple regression analysis and using the best fit, a model to predict the Relevance and Adequacy/Inadequacy of outputs of preconstruction activities (as inputs to the design phase) was proposed. Exponantial relationship between Relevance $(\mathrm{x})$ of the preconstruction activity and Adequacy (y) of the output of the of the carried out preconstruction activity (as the input to the design phase)was found as the best fit of the multiple regression analysis in the form of " $y=$ $2.6916 e^{0.024 x}$. Also, \% of Inadequacy $(\mathrm{z})=100 \%$ - \% Adequacy. Hence, a model to predict \% Inadequacy, "z $=100 \%-y=2.6916 e^{0.024 x^{\prime \prime}}$, was proposed to find out the inadequacy of the use of output of a relevant preconstruction activity.

Keywords: Preconstruction activities, Construction projects, Design phase

\section{Introduction}

Design shortcomings were identified as the main contributory factor for cost and time overruns of construction projects [1]. Further, design related issues were found among the most problematic factors [2, 3] and significant in creating issues in construction projects [4, 5]. It was revealed, failure to identify project risks at design stages was seen as a cause for failure in construction projects [6]. It was also stated design errors [5, 7], and erroneous design work/processes including attitudes of the designer [6] created issues in construction projects. Poor designs $[3,4,7]$ delay in designs [2, 4], design changes [3, 4], client driven design changes $[4,5,7]$, and change orders due to design changes [4, 5] were identified as contributing to overruns in construction projects.

More time spent during early briefing stage of the design to define the scope and complexity of the project and complete design information leads to more accurate budget estimates of the projects [7]. The following literature highlighted how the effects of design phase contributed to issues in construction projects
$[8,9,10,11,12,13,14,15,16,17,18,19,20,21$, $22,23,24]$.

Proper attention paid at the preconstruction stage [25] and proper preconstruction planning [26] was seen to contribute to the success of construction projects. Based on the above, the objectives of the study were to identify the preconstruction activities of construction projects and to analyze the adequacy of use of the outputs of preconstruction activities as inputs to the design phase of the construction projects.

Eng. Leelanath Daluwatte, B.Sc. Eng. Hons. (Moratuwa), FIE (Sri Lanka), C. Eng., P.E., M.ASCE, DBM, Dip HRM (Merit), Dip(Cleaner Production), Dip(Human Rights),

Distinguished Toastmaster, Consultant in Project Management / Construction Management / Process Improvements.

Eng. (Prof.) Malik Ranasinghe, B.Sc. Eng. Hons. (Moratuwa), M.A.Sc. (BrCol), Ph.D. (BrCol), C. Eng., Int. PE, FIE (SL), FNAS(SL) Senior Professor, Dept. of Civil Engineering, University of Moratuwa. 


\section{Literature Review}

Proper attention paid at the preconstruction phase enables the executors of construction projects to carry out professional monitoring and controlling of the two most important aspects of a project, time schedule and the budget more effectively [25]. Also it was observed when preconstruction planning was done, slippage of project schedules and overruns of the project costs could be mitigated to a great extent, if not eliminated [25]. How preconstruction planning affects cost savings and how the preconstruction planning methods promote sustainability and valuable information to investors and owners were highlighted[27]. Preconstruction planning was claimed to be a major determinant for project success [28].

Technological advancement and continuous fragmentation of the construction industry have resulted in a spiral increase in complexity of building projects. The contractors have failed to adjust their planning to more detailed level and the industry still plan the projects at the activity level. Failure to plan projects at role level, like planing for each roleplayer to carry out the activity, is widening the gap between the contractors, subcontractors and the operatives. Hence the approach may need to be replaced by allocation of adequate time during preconstruction planning to enable the main contractors to carefully collaborate with their subcontractors, consultants and suppliers to effectively carry out the preconstruction planning required at this stage of the project [26].

It was stated that preconstruction activities were predominantly analytical and administrative but were especially important since they would set the framework of cost and schedule control of the project. Also preconstruction activities were set into four subsets; 1) job setup 2) purchasing 3) performance model and 4) job startup [29].

A three-step sequential route was identified to carry out preconstruction activities during the planning or pre-design phase: 1) initial concept and scope of the work, 2) professional evaluation of the project-feasibility report and 3) appropriate data-collection [25].

Based on above reviews information and inputs related to the preconstruction phase are listed in Table 1.

Table 1 - The Identified Preconstruction Activities based on information and inputs sought during preconstruction

\begin{tabular}{|c|c|c|c|}
\hline$\#$ & Preconstruction Activity & $\begin{array}{c}(\mathrm{A}) \\
\text { Information sought } \\
\text { during } \\
\text { Preconstruction }\end{array}$ & $\begin{array}{c}\text { (B) } \\
\text { Inputs sought } \\
\text { during } \\
\text { Preconstruction }\end{array}$ \\
\hline P1 & Carry out Preliminary survey & Technical & \\
\hline P2 & Carry out Engineering survey & Technical & \\
\hline P3 & Carry out Land survey & Technical & \\
\hline $\mathrm{P} 4$ & Carry out Geotechnical survey & Technical & Sub-soil constraints \\
\hline P5 & $\begin{array}{l}\text { Study / record of Environmental } \\
\text { issues }\end{array}$ & Environmental & \\
\hline P6 & $\begin{array}{l}\text { Study / record of Rules and } \\
\text { Regulations as applicable }\end{array}$ & Statutory authorities & Legal \\
\hline P7 & $\begin{array}{l}\text { Record information about High flood } \\
\text { level }\end{array}$ & Environmental & \\
\hline P8 & $\begin{array}{l}\text { Record information about Low flood } \\
\text { level }\end{array}$ & Environmental & \\
\hline P9 & Study / record the Rainfall pattern & Environmental & \\
\hline P10 & $\begin{array}{l}\text { Study / record the Water table } \\
\text { (variations) }\end{array}$ & Environmental & Sub-soil constraints \\
\hline P11 & Study / record the Wind directions & Environmental & \\
\hline P12 & $\begin{array}{l}\text { Study / record the Variation patterns } \\
\text { of wind }\end{array}$ & Environmental & \\
\hline P13 & $\begin{array}{l}\text { Study / record the Locating of existing } \\
\text { Utilities (water, power, telecom, Wi-Fi } \\
\text { etc.) }\end{array}$ & & Energy \\
\hline
\end{tabular}




\begin{tabular}{|c|c|c|c|}
\hline P14 & Identification of the Utility agencies & & Energy, Suppliers \\
\hline P15 & $\begin{array}{l}\text { Study availability of the Utilities } \\
\text { (water, power, telecom, Wi-Fi etc.) }\end{array}$ & & Energy \\
\hline P16 & $\begin{array}{l}\text { Type of project : Design and Build, } \\
\text { Tender, Proposed }\end{array}$ & Financial, Technical & Money \\
\hline P17 & $\begin{array}{l}\text { For Tendered projects - Study of } \\
\text { Conditions of contracts }\end{array}$ & Financial, Technical & Money \\
\hline P18 & $\begin{array}{l}\text { For Tendered projects - Study of } \\
\text { Special conditions of contracts }\end{array}$ & Financial, Technical & Money \\
\hline P19 & $\begin{array}{l}\text { Investigation of Access roads } \\
\text { (capacity, width, surface, bottlenecks, } \\
\text { etc.) }\end{array}$ & Technical & Access \\
\hline P20 & $\begin{array}{l}\text { Assessment of Capacities of culverts, } \\
\text { bridges, etc. on access roads }\end{array}$ & Technical & Access \\
\hline P21 & $\begin{array}{l}\text { Investigation on availability of } \\
\text { Material }\end{array}$ & & Materials, Suppliers \\
\hline P22 & Investigation on proximity of Material & & Materials \\
\hline P23 & $\begin{array}{l}\text { Identification of requirements of } \\
\text { equipment/ machinery/ vehicles etc. }\end{array}$ & Technical & Plant Information \\
\hline P24 & $\begin{array}{l}\text { Study / record of Availability of } \\
\text { equipment/ machinery / vehicles etc. }\end{array}$ & Technical & $\begin{array}{l}\text { Plant Information, } \\
\text { Suppliers }\end{array}$ \\
\hline P25 & $\begin{array}{l}\text { Study / record of Availability of Sub } \\
\text { Contractors }\end{array}$ & & $\begin{array}{l}\text { Availability of skills, } \\
\text { Suppliers }\end{array}$ \\
\hline P26 & $\begin{array}{l}\text { Study / record of Requirement and } \\
\text { availability of Special Sub Contractors }\end{array}$ & & $\begin{array}{l}\text { Availability of skills, } \\
\text { Suppliers }\end{array}$ \\
\hline P27 & $\begin{array}{l}\text { Study / record of Requirement and } \\
\text { availability of Skilled Manpower }\end{array}$ & & $\begin{array}{l}\text { Availability of skills, } \\
\text { Suppliers }\end{array}$ \\
\hline P28 & $\begin{array}{l}\text { Study / record of Requirement and } \\
\text { availability of Un-skilled Manpower }\end{array}$ & & Availability of skills. \\
\hline P29 & $\begin{array}{l}\text { Assessment of the leadership required } \\
\text { - Project Manager etc.- to drive the } \\
\text { project }\end{array}$ & & People \\
\hline P30 & $\begin{array}{l}\text { Study / record of Availability of } \\
\text { knowledge to do the project - core and } \\
\text { support areas }\end{array}$ & & People \\
\hline P31 & $\begin{array}{l}\text { Study / record of Adequacy of the } \\
\text { skills to do the project - core and } \\
\text { support areas }\end{array}$ & & Availability of skills. \\
\hline P32 & $\begin{array}{l}\text { Assessment of Attitude of the } \\
\text { Individuals / Team towards } \\
\text { delivering the project }\end{array}$ & & People \\
\hline P33 & $\begin{array}{l}\text { Identification of corrective measures, } \\
\text { eg. Training to rectify the gaps found }\end{array}$ & & People \\
\hline P34 & $\begin{array}{l}\text { Study / record of Possible of Social } \\
\text { issues }\end{array}$ & & $\begin{array}{l}\text { Social attitudes, } \\
\text { Social expectations }\end{array}$ \\
\hline P35 & $\begin{array}{l}\text { Study / record of Possible } \\
\text { Neighbourhood issues }\end{array}$ & & Social expectations \\
\hline P36 & $\begin{array}{l}\text { Study / record of Possible Religious } \\
\text { issues }\end{array}$ & & Social expectations \\
\hline P37 & $\begin{array}{l}\text { Study / record of Possible Political } \\
\text { issues }\end{array}$ & & Social expectations \\
\hline P38 & Study / record of Stakeholder issues & & $\begin{array}{l}\text { Customers, } \\
\text { Shareholders, } \\
\text { Suppliers }\end{array}$ \\
\hline
\end{tabular}

Note: Literature reviews on [25] and [26] revealed,Information sought during Preconstruction (re: Column 3; Table 1) and Inputs sought during Preconstruction (re: Column 4; Table 1) respectively. 


\section{Methodology and Data Collection}

This study focuses on a real problem in the construction industry. As such, applied research method, a mix between quantitative and qualitative types of research methods together with descriptive methods and analytical research method [30,31] were used to develop the research methodology.

A structured questionnaire to collect data regarding relevance of the identified preconstruction activities (Table 1) to the projects and their possible effects on the design phase of the project/s was developed. Data on the Relevance and Adequacy of preconstruction activities as inputs to the design phase of construction projects were collected from the respondents using the questionnaire which was tested through a pilot survey. The respondents reported the Relevance and then Adequacy of preconstruction activities in a Likert scale of percentages (as given in the questionnaire). Even though the Likert scale is ordinal, when the scale is symmetric and equidistant it behaves like an interval-level measurement and if well presented it approximates to an interval-level measurement.

The data was collected from different sectors of construction like; building, roads, bridge, water supply, steel construction, from responsible professionals involved in those projects.
Responses were collected from thirty two construction projects for the identified thirty eight preconstruction activities regarding their Relevance and Adequacy to the designphase of the project. Based on the responses, data from those preconstruction activities which were identified as Relevant and 100\% Adequate for the projects were used (see Table 2) for the analysis which is described in section 4.

\section{Analysis and Discussion}

\subsection{Analysis of Data}

\subsubsection{General}

Responses received from the questionnaire were verified for clarity from the respondents and analysed to find meaningful relationships between the Relevance of preconstruction activities and Adequacy (or Inadequacy) level of their input to the design phase.

4.1.2 Relationship between Relevance and Adequacy of preconstruction activities

The data highlighted a possible relationship between the responses on Relevance of the preconstruction activities and the Adequacy of use of the outputs of preconstruction activities as inputs to the design of the construction projects. A model to predict the relationship between relevance and adequacy (or inadequacy) of preconstruction activities would be useful during the design phase to gauge the contribution of the preconstruction activities.

Table 2 - List of Projects with relevance and adequacy of analysis of preconstruction activities based on the responses from the industry.

\begin{tabular}{|c|l|c|c|c|c|}
\hline$\#$ & Preconstruction Activity & $\begin{array}{c}\text { Relevant } \\
\text { number } \\
\text { of } \\
\text { Projects }\end{array}$ & $\begin{array}{c}\text { Percentage } \\
\text { of Relevant } \\
\text { number of } \\
\text { Projects }\end{array}$ & $\begin{array}{c}\text { Number of } \\
100 \% \\
\text { Adequate } \\
\text { inputs of a } \\
\text { project } \\
(\mathrm{Y})\end{array}$ & $\begin{array}{c}\text { Percentage } \\
\text { of } 100 \% \\
\text { Adequate } \\
\text { inputs }\end{array}$ \\
\hline P1 & Carry out Preliminary survey & 31 & $97 \%$ & 12 & $38 \%$ \\
\hline P2 & Carry out Engineering survey & 31 & $97 \%$ & 14 & $44 \%$ \\
\hline P3 & Carry out Land survey & 30 & $94 \%$ & 13 & $41 \%$ \\
\hline P4 & Carry out Geotechnical survey & 25 & $78 \%$ & 7 & $22 \%$ \\
\hline P5 & $\begin{array}{l}\text { Study / record of } \\
\text { Environmental issues }\end{array}$ & 29 & $91 \%$ & 9 & $9 \%$ \\
\hline P6 & $\begin{array}{l}\text { Study / record of Rules and } \\
\text { Regulations as applicable }\end{array}$ & 32 & $100 \%$ & 10 & $31 \%$ \\
\hline P7 & $\begin{array}{l}\text { Record information about High } \\
\text { flood level }\end{array}$ & 20 & $63 \%$ & 6 & $19 \%$ \\
\hline
\end{tabular}




\begin{tabular}{|c|c|c|c|c|c|}
\hline P8 & $\begin{array}{l}\text { Record information about Low } \\
\text { flood level }\end{array}$ & 14 & $44 \%$ & 2 & $6 \%$ \\
\hline P9 & $\begin{array}{l}\text { Study / record the Rainfall } \\
\text { pattern }\end{array}$ & 20 & $63 \%$ & 3 & $9 \%$ \\
\hline P10 & $\begin{array}{l}\text { Study / record the Water table } \\
\text { (variations) }\end{array}$ & 19 & $59 \%$ & 7 & $22 \%$ \\
\hline P11 & $\begin{array}{l}\text { Study / record the Wind } \\
\text { directions }\end{array}$ & 13 & $41 \%$ & 7 & $22 \%$ \\
\hline P12 & $\begin{array}{l}\text { Study / record the Variation } \\
\text { patterns of wind }\end{array}$ & 8 & $25 \%$ & 3 & $9 \%$ \\
\hline P13 & $\begin{array}{l}\text { Study / record the Locating of } \\
\text { existing Utilities (water, power, } \\
\text { telecom, Wi-Fi etc.) }\end{array}$ & 32 & $100 \%$ & 13 & $41 \%$ \\
\hline P14 & $\begin{array}{l}\text { Identification of the Utility } \\
\text { agencies }\end{array}$ & 29 & $91 \%$ & 14 & $44 \%$ \\
\hline P15 & $\begin{array}{l}\text { Study availability of the Utilities } \\
\text { (water, power, telecom, Wi-Fi } \\
\text { etc.) }\end{array}$ & 32 & $100 \%$ & 14 & $44 \%$ \\
\hline P16 & $\begin{array}{l}\text { Type of project : Design and } \\
\text { Build, Tender, Proposed }\end{array}$ & 29 & $91 \%$ & 11 & $34 \%$ \\
\hline P17 & $\begin{array}{l}\text { For Tendered projects - Study of } \\
\text { Conditions of contracts }\end{array}$ & 29 & $91 \%$ & 11 & $34 \%$ \\
\hline P18 & $\begin{array}{l}\text { For Tendered projects - Study of } \\
\text { Special conditions of contracts }\end{array}$ & 25 & $78 \%$ & 11 & $34 \%$ \\
\hline P19 & $\begin{array}{l}\text { Investigation of Access roads } \\
\text { (capacity, width, surface, } \\
\text { bottlenecks, etc.) }\end{array}$ & 28 & $88 \%$ & 11 & $34 \%$ \\
\hline P20 & $\begin{array}{l}\text { Assessment of Capacities of } \\
\text { culverts, bridges, etc. on access } \\
\text { roads }\end{array}$ & 22 & $69 \%$ & 10 & $31 \%$ \\
\hline P21 & $\begin{array}{l}\text { Investigation on availability of } \\
\text { Material }\end{array}$ & 31 & $97 \%$ & 8 & $25 \%$ \\
\hline P22 & $\begin{array}{l}\text { Investigation on proximity of } \\
\text { Material }\end{array}$ & 28 & $88 \%$ & 10 & $31 \%$ \\
\hline P23 & $\begin{array}{l}\text { Identification of requirements of } \\
\text { equipment/ machinery/ } \\
\text { vehicles etc. }\end{array}$ & 32 & $100 \%$ & 8 & $25 \%$ \\
\hline P24 & $\begin{array}{l}\text { Study / record of Availability of } \\
\text { equipment/ machinery / } \\
\text { vehicles etc. }\end{array}$ & 31 & $97 \%$ & 7 & $22 \%$ \\
\hline P25 & $\begin{array}{l}\text { Study / record of Availability of } \\
\text { Sub Contractors }\end{array}$ & 27 & $84 \%$ & 8 & $25 \%$ \\
\hline P26 & $\begin{array}{l}\text { Study / record of Requirement } \\
\text { and availability of Special Sub } \\
\text { Contractors }\end{array}$ & 24 & $75 \%$ & 7 & $22 \%$ \\
\hline P27 & $\begin{array}{l}\text { Study / record of Requirement } \\
\text { and availability of Skilled } \\
\text { Manpower }\end{array}$ & 31 & $97 \%$ & 3 & $9 \%$ \\
\hline P28 & $\begin{array}{l}\text { Study / record of Requirement } \\
\text { and availability of Un-skilled } \\
\text { Manpower }\end{array}$ & 28 & $88 \%$ & 2 & $6 \%$ \\
\hline P29 & $\begin{array}{l}\text { Assessment of the leadership } \\
\text { required - Project Manager etc.- } \\
\text { to drive the project }\end{array}$ & 29 & $91 \%$ & 12 & $38 \%$ \\
\hline P30 & $\begin{array}{l}\text { Study / record of Availability of } \\
\text { knowledge to do the project - } \\
\text { core and support areas }\end{array}$ & 32 & $100 \%$ & 10 & $31 \%$ \\
\hline
\end{tabular}




\begin{tabular}{|c|l|c|c|c|c|}
\hline P31 & $\begin{array}{l}\text { Study / record of Adequacy of } \\
\text { the skills to do the project - core } \\
\text { and support areas }\end{array}$ & 31 & $97 \%$ & 8 & $25 \%$ \\
\hline P32 & $\begin{array}{l}\text { Assessment of Attitude of the } \\
\text { Individuals / Team towards } \\
\text { delivering the project }\end{array}$ & 28 & $88 \%$ & 10 & $31 \%$ \\
\hline P33 & $\begin{array}{l}\text { Identification of corrective } \\
\text { measures, eg. Training to rectify } \\
\text { the gaps found }\end{array}$ & 24 & $75 \%$ & 3 & $9 \%$ \\
\hline P34 & $\begin{array}{l}\text { Study / record of Possible of } \\
\text { Social issues }\end{array}$ & 24 & $75 \%$ & 8 & $6 \%$ \\
\hline P35 & $\begin{array}{l}\text { Study / record of Possible } \\
\text { Neighbourhood issues }\end{array}$ & 28 & $88 \%$ & 1 & $6 \%$ \\
\hline P36 & $\begin{array}{l}\text { Study / record of Possible } \\
\text { Religious issues }\end{array}$ & 9 & $28 \%$ & 1 & $3 \%$ \\
\hline P37 & $\begin{array}{l}\text { Study / record of Possible } \\
\text { Political issues }\end{array}$ & 10 & $31 \%$ & $63 \%$ & 1 \\
\hline P38 & $\begin{array}{l}\text { Study / record of Stakeholder } \\
\text { issues }\end{array}$ & 20 & & $3 \%$ \\
\hline
\end{tabular}

\section{Note on Table 2 - Total number of projects considered is 32}

For example, from the responses received for the preconstruction activity, (P25)from Table 2, "Availability of sub-contractors", Relevant number of Projects out of all Projects $=27$ (column 3 of Table 2)andnumber of 100\% Adequate inputs of a project out of all Projects $=8($ column 5 of Table 2$)$, and for the number of projects considered $=32$, then;

a. Percentage of Relevant number of Projects out of all Projects, $x=(27 / 32) * 100=84 \%$, and,

b. Percentage of $100 \%$ Adequate inputs to the projects, $\mathrm{y}=(8 / 32) * 100=25 \%$

4.1.3 Deriving the appropriate relationship between relevance and $100 \%$ adequacy for a preconstruction activity as an input to the design

When a preconstruction activity is relevant for a construction project, it appears the output of the activity (as the input) to the design phase has to be adequate to satisfy the purpose of an effective design. Hence finding a relationship between the two, relevance and adequacy (as explained) is done as given below.

Line fitting was utilized to test the relationship between relevance of the preconstruction activities and adequacy of the outputs of preconstruction activities as inputs to the design of the construction projects. Using regression analysis, the most appropriate relationship was determined as the exponential relationship between the variables Relevance and Addequacy, as it had the highest coefficient of determination, $\mathrm{R}^{2}(=0.4)$, being the closest to the perfect fit $(=1.0)$. Table 3 below gives details of gives the possible types of relationships arrived using regression analysis). Accordingly the exponential relationship between the variable 'Relevance' and dependent variable 'Adequacy' was found to be the most appropriate relationship. $y=2.6916 e^{0.024 x}$

Table 3 - Results of the regression analysis: Relevance \% (x) and Adequacy \% (y)

\begin{tabular}{|l|c|l|}
\hline \multicolumn{3}{|c|}{ Relationship Relevance $(\mathrm{x})$ and Adequacy $(\mathrm{y})$} \\
\hline Type of Relationship & $\mathrm{R}^{2}$ & \multicolumn{1}{c|}{ Equation } \\
\hline Exponential & 0.4 & $y=2.6916 e^{0.024 x}$ \\
\hline Power & 0.38 & $y=0.0448 x^{1.3884}$ \\
\hline Polynomial & 0.37 & $y=0.0034 x^{2}-0.0785 x+6.7274$ \\
\hline Linear & 0.36 & $y=0.3706 x-6.1054$ \\
\hline Logarithmic & 0.33 & $y=20.88 \ln (x)-66.898$ \\
\hline
\end{tabular}


When a designer needs to estimate the adequacyof theoutcome of a preconstruction activityas input to the design he can use the model given by equation (1). For example, consider the preconstruction activity, 'Geotechnical Survey', which is $100 \%$ relevant to the project. Using equation (1) the adequacy of the preconstruction activity 'Geotechnical Survey', $y=2.6916 \mathrm{e}^{0.024 \times 100}=30 \%$. Also, \% Inadequacy $(z)=100 \%$ - \% Adequacy $(y)$.

i.e. $\%$ of Inadequacy $(z)=100 \%-2.6916 \mathrm{e}^{0.024 x}=$ $70 \%$

Figure 1 was derived using, equation (1), the most appropriate relationship for Relevance and Inadequacy, $\mathrm{z}=100 \%-2.6916 \mathrm{e}^{0.024 x}$ as discussed above. Using the model in Figure 1, when the relevance of an activity is known, appropriate inadequacy level of the input for the design can be found. With the above finding the options available for the designer are;

i.Improvethe reliability of available data for the preconstruction activity to decrease/eliminate Inadequacy level of the activity by obtaining additional data(say data from further boreholes)beforecommencing the design.

ii.Designer optsfor a judgement based on his knowledge, experience, exposure etc. and continueswith the design, irrespective of the $70 \%$ inadequate value derived from the model.

If option i) was considered for the design, to rectify the identified faults, the designer would have to improve the input of the data of the activity. This would result in possible overruns in time (time the design team used in working on option ii), possible delay in construction (as a practice construction follows design until the design is rectified) and increase in costs (possible costs due to variations in a construction activity / activities).

Possible errors could surface;

a) During the design phase before issuing drawings for the construction phase.

b) After construction drawings were issued and design faults were identified during the construction phase.

c) During operational phase of the project.

If option ii) was taken by the designer, and it resulted in an effective design, then there would be no issue. Such a decision would depend significantly on the knowledge, experience, exposure, etc. of the designer.

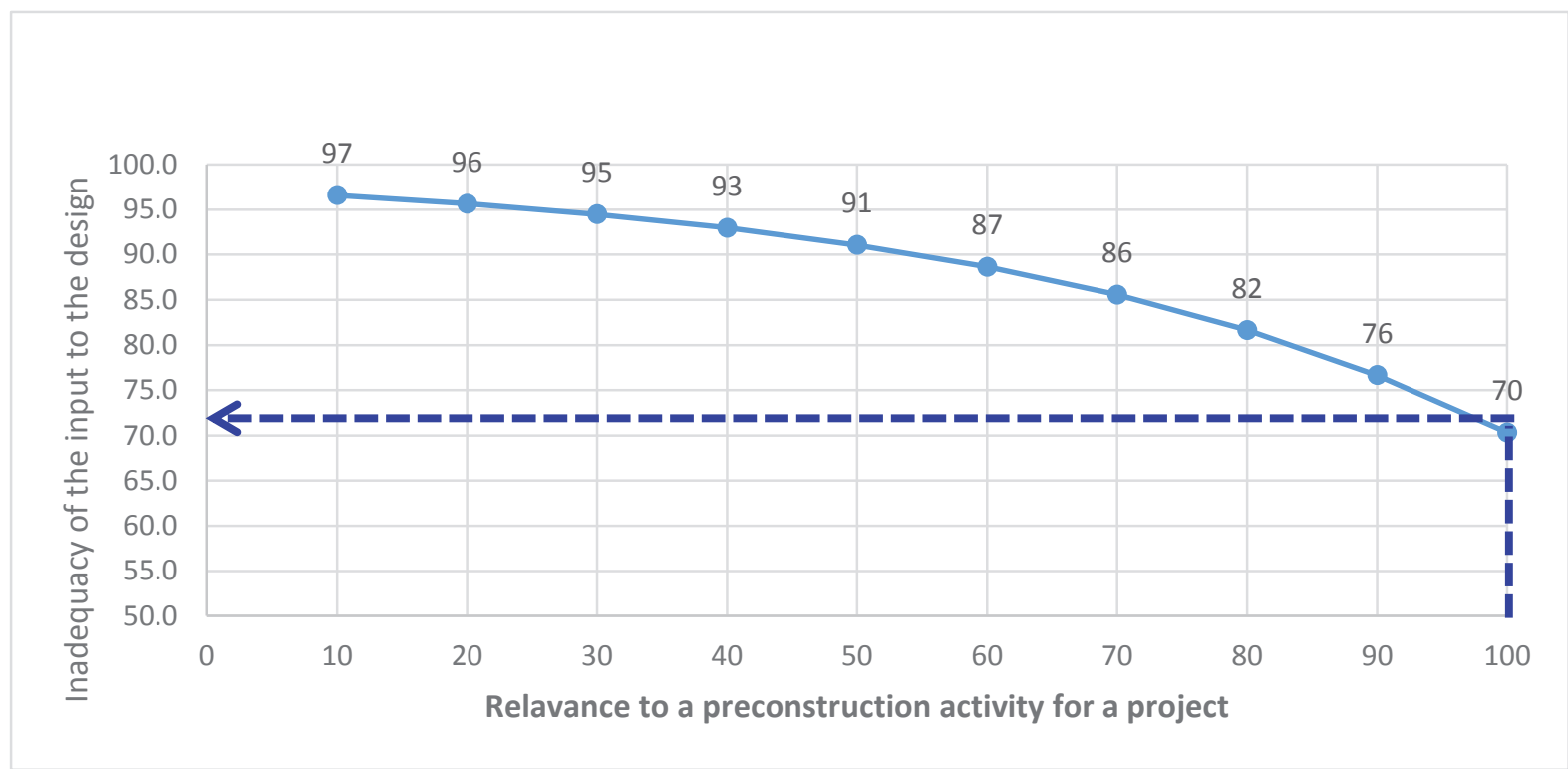

Figure 1 - Relevance of a preconstruction activity for a project vs Inadequacy of the output of the activity as the input to the design 


\subsection{Limitations}

1. List of preconstruction activities identified and used in the study could be a subset of the possible comprehensive list of preconstruction activities that are required during the design phase.

2. The responses received from experts, based on the questionnaire survey, was limited to the professionals from the construction industry in Sri Lanka. Hence, the applicability of the results may be limited to use in the Sri Lankan construction industry.

\subsection{Further research}

This study focused on the $100 \%$ adequacy of the inputs of the analysis of the relevant preconstruction activities for the design phase. Hence it could be possible to carryout further research on the preconstruction activities with adequacy of inputs of the analysis is less than $100 \%$. It is also observed that there is room for improvements on the proposed model which gives a relationship between the Relevance andInadequacy of the inputs to the design phase by further research, for example, exploring of the limitations of this study.

\section{Conclusions}

Following conclusions are drawn from the study.

- Thirty eight preconstruction activities were identified from the literature review, as relevant inputs to the design phase of the construction projects. These thirty eight preconstruction activities could possibly be a subset of a number of preconstruction activities applicable to the construction industry.

- $\quad$ Based on the responses of the projects considered adequacy levels of the relevant inputs to the design by the outputs of the preconstruction activities were, highest at $44 \%$, average at $23 \%$ and the lowest at $3 \%$. Above reflects that none of the inputs from preconstruction activities hasnot even reached an adequacy level of $50 \%$.
- Inadequacy level of the relevant inputs to the design by the outputs of the preconstruction activities of a construction project was at a minimum of $56 \%$ (\% Adequacy $+\%$ Inadequacy $=100 \%$ ).

- A model to predict the relationship between Relevance (x) and Adequacy (y)/ Inadequacy (z) of outputs of preconstruction activities as inputs to the design phase was developed as $y=$ $2.6916 e^{0.024 x}$ for Adequacy or $z=100$ $2.6916 e^{0.024 x}$ for Inadequacy. A designer could use this model to predict the inadequacy of the output of a preconstruction activity (as the input to the design phase) for a known relevance of the preconstruction activity.

\section{References}

1. Daluwatte, L. and Ranasinghe, M. (2017), Contributory factors for Cost and Time Overruns of Construction Projects, Transactions 2017 Part B, Technical Papers, The Institutionof Engineers, Sri Lanka, pp. 89-96.

2. Morris, S. (1990), Cost and time overruns in public sector projects. Economic and Political Weekly, Vol. 25, No. 47, pp.M154-M168, November 24, 1990.

3. Akinsiku, O. E. and Akinsulire A. (2012) Stakeholders' perception of the causes and effects of construction delays on project delivery KICEM Journal of Construction Engineering and Project Management Online ISSN 2233-9582

$\underline{25}$ www.jcepm.org http://dx.doi.org/10.6106/ JCEPM.2012.2.4.025.

4. Vu H.A., Wang, J., Min, L., Mai, S.H. and Nguyen, H. P. (2016) Research on cost overrun risk of construction phase of Vietnam highway international contracting project, Engineering, 2016, 8, pp. 86-98, Published Online March 2016 in SciRes. http://www.scirp.org/journal/eng http://dx.doi.org/10.4236/eng.2016.83011.

5. Desai, N. J., S., Pitroda, J. and Bhavsar, J.J. (2015) A review on change order and assessing causes affecting change order in construction, Journal for International Academic Research for Multidisciplinary Impact Factor 1.625, ISSN: 2320-5083, Volume 2, Issue 12, January 2015. 
6. Edwards, P., Bowen, P., Hardcastle, C., and Stewart, P. (2009) Identifying and communicating project stakeholder risks. Building a sustainable future: pp. 776-785. doi: 10.1061/41020(339)79 ASCE.

7. Olawale, Y. A. and Sun, M. (2010) Cost and time control of construction projects: Inhibiting factors and mitigating measures in practice. pp. 509-526 Published online: 15 Jun 2010.

8. Kaveen, S., Aleem, M. I. A. and Thaarrini, J. (2015) Application of value engineering in construction project to predict time and cost overrun - An overview; International Journal of Scientific Engineering and Applied Science (IJSEAS) - Volume-1, Issue-9, December 2015ISSN: 2395-3470 www.ijseas.com.

9. Ghanim A. Bekr., G. A. (2015) Identifying factors leading to cost overrun in construction projects in Jordan, Journal of Construction engineering, Technology \& Management, Vol 5, No 3.

10. Sepasgozar, S. M. E., Razkenari, M.A. Barati, K. and Modares, T. (2015) The importance of new technology for delay mitigation in construction projects, American Journal of Civil Engineering and Architecture 3.1 (2015): pp. 15-20.

11. El-Kholy, A. M. (2015) Predicting cost overrun in construction projects, International Journal of Construction Engineering and Management p-ISSN: 2326-1080 e-ISSN:2326-1102 2015; 4(4): pp. 95-105.

12. Muhammad Akram, M., Memon, N. A., Ali, T. H. and Siddiqui, F. (2015). Developing an expert system for controlling cost and time overrun in construction projects. Conference: Sustainable Development through Advancements in Civil Engineering. June 12-13, 2015, Karachi, Pakistan.

13. Mahadik, U. A. (2015). Cost reduction in construction projects. International Journal of Engineering Technology, Management and Applied Sciences. September 2015, Volume 3, Special Issue, ISSN 2349-4476.

14. Patel, C. H., Chaturvedi, H., Rao, M. R., Katta, P. and Prasad, K. N. N. (2015). An analysis of cost and time overruns in construction projects. NICMAR Journal of Construction Management, Vol. XXX April - June 2015 No. II.

15. Buys, F (2015) Five causes of project delay and cost overrun, and their mitigation measures. Paper, LinkedIn.com.
16. Desai, N. J., S., Pitroda, J. and Bhavsar, J.J. (2015) A review on change order and assessing causes affecting change order in construction, Journal for International Academic Research for Multidisciplinary Impact Factor 1.625, ISSN: 2320-5083, Volume 2, Issue 12, January 2015.

17. Rahman, I.S., Memon, A. H., Nagapan, S. and Latif, Q. B. A.I. (2012). Time and cost performance of construction projects in southern and central regions of peninsular Malaysia. 2012 IEEE Colloquium on Humanities, Science and Engineering (CHUSER).

18. Memon A.H., Abdullah, M. A. H. I. A. M. R. and Azis, A. A. (2010). Factors affecting construction cost in mara large construction project: Perspective of project management consultant. International Journal of Construction Engineering \& Technology Vol 1, No 2, December 2010.

19. Long, N.D., Ogunlana, S., Quang, T. and Lam, K. C. (2004) Large construction projects in developing countries: a case study from Vietnam, International Journal of Project Management, Vol.22: 553-561.

20. Mukuka, M., Aigbavboa, C. and Thwala, W. (2015). Effects of construction projects schedule overruns: A case of the Gauteng Province, South Africa,http://creativecommons.org/licenses/by-ncnd/4.0/). Peer-review under responsibility of AHFE Conference.

21. Olawale, Y., and Sun M. (2010). Cost and time control of construction projects: Inhibiting factors and mitigating measures in practice. Construction Management and Economics, 28 (5), pp.509 - 526.

22. Memon, A. H. (2014) Contractor perspective on time overrun factors in Malaysian construction projects. International Journal of Science, Environment ISSN 2278-3687 $(\mathrm{O})$ and Technology, Vol. 3, No 3, 2014, 1184 - 1192.

23. Azhar, A., Farooqui, R. U. and Ahmed, S.M.(2008) Cost overrun factors In construction industry of Pakistan, First International Conference on Construction In Developing Countries (ICCIDC-I) "Advancing and Integrating Construction Education, Research \& Practice" August 4-5, 2008, Karachi,Pakistan.

24. Emam, H., Farrell, P. and Abdelaal, M. (2015) Causes of delay on large Infrastructure projects in Qatar, Conference: 31st Annual ARCOM Conference, At Lincoln, UK. DOI: 10.13140/RG.2.1.1732.0400. 
25. Al-Reshaid, K., Kartam, N., Tewari, N. and Albader, H. (2005) A project control process in pre-construction phases: Focus on effective methodology, Article in Engineering Construction \& Architectural Management 12(4):351-372 DOI: 10.1108/09699980510608811.

26. Gidado, K. (2004) Enhancing the prime contractors preconstruction planning, Journal of Construction Research, Vol. 5, No. 1 (2004) pp.87-106.

27. Kreitler, C. (2011) Effect of precondition planning on costs and sustainability, Thesis for Master of Science in Building Construction, University of Florida, USA.

28. Anderson, C. and Rosenberg, L. (2012) The preconstruction planning process from a site manager perspective, Chalmers University of Technology, Göteborg, Sweden, Master's Thesis 2012:18.

29. Mueller, F.W. (1986). Preconstruction Activities: Integrated Cost and Schedule Control for Construction Projects. Springer, Boston, MA, DOI: 10.1007/978-1-4615-97506_15.

30. Nallaperumal, K. (2013) Engineering Research Methodology, A Computer Science and Engineering and Information and Communication Technologies Perspective.FirstEdition http://www.engineeri ngresearchjournal.com.

31. Saunders, M.N.K., Lewis, p. and Thornhill, 2012, Research Methods for Business Students pp. 419-420. 